Summer 2012

\title{
Against Wishful Scholarship: The Importance of Engel
}

\author{
Duncan McCargo \\ University of Leeds, d.j.mccargo@leeds.ac.uk
}

Follow this and additional works at: https://www.repository.law.indiana.edu/ijgls

Part of the Constitutional Law Commons, and the International Law Commons

\section{Recommended Citation}

McCargo, Duncan (2012) "Against Wishful Scholarship: The Importance of Engel," Indiana Journal of Global Legal Studies: Vol. 19 : Iss. 2 , Article 5.

Available at: https://www.repository.law.indiana.edu/ijgls/vol19/iss2/5

This Comment is brought to you for free and open access by the Law School Journals at Digital Repository @ Maurer Law. It has been accepted for inclusion in Indiana Journal of Global Legal Studies by an authorized editor of Digital Repository @ Maurer Law. For more information, please contact rvaughan@indiana.edu.

\section{$\Psi$}

JEROME HALL LAW LIBRARY

INDIANA UNIVERSITY

Maurer School of Law
Blooming ton 


\title{
Against WishFul Scholarship: The IMPORTANCE OF ENGEL
}

\author{
DUNCAN MCCARGO*
}

David Engel's Article on global consciousness ${ }^{1}$ crystallizes a set of arguments he recently made in a number of publications, most notably in his coauthored book Tort, Custom, and Karma. ${ }^{2}$ To me, the main point of his argument is by no means limited to questions of law or globalism. Rather, he argues against the dominant mode of writing among scholars across a wide range of social science and related disciplines-a mode of writing that might best be termed "wishful scholarship." In wishful scholarship, the starting point of the author is the world as she or he wishes to see it, or wishes to see it become.

When an academic begins with a strongly held normative premise, which could be anything from "Nigeria should become more democratic" to "Thailand would benefit from producing more cause lawyers" to "Britain ought to have a written constitution," the results are eminently predictable. Either insufficient evidence will be uncovered to validate the normative premise, and the subjects of study will be found wanting, implicitly or explicitly, or sufficient evidence will be uncovered to support the normative premise, which will therefore be validated and form the basis of teleological assumptions about the nature of change in the society being studied. In other words, either Nigeria is not becoming more democratic-in which case there is something wrong with Nigeria-or Nigeria is becoming more democratic-in which case the researcher has been proved right. The alternative explanations-that Nigeria is not becoming more democratic and that there is something wrong with the researcher's point of view, or that Nigeria is becoming more democratic, but in ways that the researcher failed to graspcannot be seriously contemplated. Yet, as Engel implies, the least

* Professor of Southeast Asian Politics, School of Politics and International Studies, University of Leeds; Visiting Scholar, Weatherhead East Asian Institute, Columbia University.

1. See David M. Engel, Vertical and Horizontal Perspectives on Rights Consciousness, 19 IND. J. GLOBAL LEGAL STUD. 423 (2012).

2. See generally DaVID M. ENGEL \& JARUWAN S. ENGEL, TORT, CuSTOM, AND KaRMA: GLOBALIZATION AND LEGAL CONSCIOUSNESS IN THAILAND (2010).

Indiana Journal of Global Legal Studies Vol. 19 \#2 (Summer 2012)

(C) Indiana University Maurer School of Law 
palatable explanation may well be the most likely. ${ }^{3}$ Nigeria is not becoming more democratic, and the researcher is so overladen with assumptions that it never occurs to her that her own wishful scholarship is the core problem, rather than real or supposed deficiencies of the Nigerian political order. Engel's Article is a brilliantly crafted plea for us to understand the world as it is and not as we would wish it to become. The simple response is that we should do exactly as Engel suggests.

Nevertheless, it is hard to blame individuals for engaging in wishful scholarship. Take the question of the prospects for a military coup in Thailand. According to the logic of democratization theory, military coups have become obsolete in a country that has regular elections, has a number of well-established political parties, and has seen regular mass movements calling for greater freedom and openness. ${ }^{4}$ Yet, Thailand has experienced numerous military coups since 1932, most recently in 1991 and $2006 .{ }^{5}$ By granting media interviews supporting expectations that another coup could take place, any reputable political scientist-Thai or foreign-would help create the conditions for such a coup. It is, therefore, unsurprising that many political scientists, myself included, would be reluctant to publicly predict another military coup, even one that we fully expected to take place. In this sense, wishful scholarship may become a political act. Not talking about something may make it less likely to happen; talking about it may make it more likely. Defining the responsibilities of a scholar who believes in universal human rights or opposes the death penalty is not always simple. Who can help feeling uneasy, for example, that a Japanese suspect who has not yet been tried can sit in a Thai jail for several weeks after allegedly stealing items worth two dollars from a convenience store ${ }^{6}$ Wishful scholarship does have its place, and sometimes standing at the sidelines when faced with injustice or the naked abuse of power is neither possible nor appropriate. What is most important is that wishful scholars practice in a self-conscious, reflective, and self-critical manner.

The second key argument in Engel's Article is his own advocacy of "legal pluralism"-the coexistence of multiple levels of legal reality, in which formal mechanisms such as criminal codes, trial proceedings, and

3. Engel, supra note 1, at 433-34

4. See, e.g., Joseph Kahn, The Latest Asian Miracle: Chaos Without Coups, N.Y. TIMES, July 26, 1998, available at http:/www.nytimes.com/1998/07/26/weekinreview/theworld-the-latest-asian-miracle-chaos-without-coups.html?pagewanted=all\&src=pm.

5. See generally 38 JoURNAL OF CONTEMPORARY ASIA 1 (Michael Connors \& Kevin Hewison, eds., 2008) (discussing the 2006 military coup in Thailand in detail).

6. An actual case I have recently encountered. 
sentencing guidelines coexist with very different notions of justice based on cultural norms and assumptions or the extra-constitutional power of important institutions. ${ }^{7}$ Since his brilliant early monographs on Thailand were published in the $1970 \mathrm{~s}$, ${ }^{8}$ David Engel has been the most gifted advocate of a highly nuanced approach to Southeast Asian studies, which sees no contradiction between formal and informal notions of power, and understands perfectly that cultural perspectives are neither an alternative nor an add-on to more conventional understandings when scrutinizing politics, law, history, and society. Rather, countries such as Thailand need to be viewed through a prism that allows for multiple readings of the same events and issues. Again, the pluralist prism should be the primary lens deployed by researchers in a range of disciplines, including, but not limited to, those studying law and society.

I have a long-standing connection with a family of gun dealers in Thailand. The family has experienced many troubles over the nearly thirty years I have known them, ranging from business bankruptcies to marital breakups to traffic accidents. I had always assumed that such adverse events were part of the normal life cycle of a large Thai family-and that the traffic accidents probably resulted mainly from them driving too fast. My solution to the family members' problems was to urge them to exercise greater caution in all their dealings and to avoid risk wherever possible. However, a Thai friend offered a completely different explanation for the family's troubles. The gun business was closely linked to criminal activities that constituted bap, or Buddhist demerits. Whenever someone uses a gun for a bad purpose and that gun had passed through the hands of the family, the family shares in the associated demerit-resulting in a catalog of calamities. The solution suggested by my (Western-educated, incidentally) Thai friend was that the family engage in merit-making activities, such as offering substantial donations to temples or supporting charities for the disadvantaged. In this way, they could store up sufficient bun (merit) to offset the bap derived from their business activities.

Am I saying that I believe my Thai friend was right? Frankly, no: I have to say that I remain completely unconvinced by the bun/bap explanation. But the explanation served to wrong-foot me-to remind

7. Engel, supra note 1, at 439 .

8. See generally DAVID M. ENGEL, LAW AND KINGSHIP IN THAILAND DURING THE REIGN of King ChUlalongkorn (1975); David M. ENgel, Code AND Custom IN A THaI PROVINCIAL COURT: THE INTERACTION OF FORMAL AND INFORMAL SySTEMS OF JUSTICE (1978). 
me that for all my experience as a scholar of Southeast Asia, I could easily miss a whole dimension of what was going on around me. Understandings based on popular religion are at the core of how Thais view the world they inhabit. The idea that uneducated people view the world in superstitious terms and educated people view it through a prism of rationality is deeply flawed. Many of Thailand's most famous and respected social scientists never leave the house without donning special sacred amulets-often worn on chains around their neckswhich provide them with protection. David Engel's notion of legal pluralism is an important one, but one that can be generalized well beyond the legal sphere. The nonwishful scholar must also be a pluralminded scholar, or perhaps better still, a plurally mindful scholar.

The third key idea in Engel's Article is one I am less enthusiastic about: his distinction between "vertical" and "horizontal" perspectives. He makes a superb case for what he terms the horizontal perspectivelooking at the world from the viewpoint of ordinary people-rather than looking down on individual human beings from the lofty heights of grand notions such as universal rights and international standards of justice." At the same time, the meaning of his terms "vertical" and "horizontal" was not immediately clear to me until I read the Article quite closely. Engel is really talking about the difference between datadriven and theory-driven research, the difference between fieldworkbased research and an extended literature review, the difference between top-down and bottom-up thinking, and the difference between elite and grassroots perspectives. I am not entirely sure how to capture all those distinctions in a neat phrase or pair of opposing adjectives, but I would like to suggest that "vertical" and "horizontal" will not quite do the trick. A truly horizontal perspective would risk being blind to the hierarchies of power relations that are at the core of all societies, especially Asian societies. I would favor drawing a sharp distinction between perspectives that are "abstract" and those that are "grounded," and I am willing to risk the opprobrium of being branded a mere empiricist by asserting that I would always privilege the grounded over the abstract.

David Engel's Article is a wake-up call, a challenge to intellectual complacency, and a rebuke to the academically indolent. He decries wishful scholarship, champions the pluralist prism, and cheers the grounded argument against the greater allure of merely abstract musings. Following his prescriptions involves hard work. It is much easier to write from a singular position defending a lofty cause that you support than to follow the less-trodden path of the fieldworker, the

9. Engel, supra note 1 , at 425 . 
participant observer, the dogged interviewer, and the loiterer-withintent. Although he never says as much, Engel is urging us to get out of our offices and to leave our libraries. Above all, he is urging us to go offline, in more ways than one, in pursuit of important and potentially disturbing truths. Let's go. 


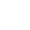

